\title{
Research methodology of the concept of "environmental and legal culture" as a phenomenon in the theory of Russian environmental law
}

\author{
Larisa Gennadievna Klyukanova ${ }^{1}$ \\ Saint Petersburg State University, Department of the Legal Protection of Environment of the Law \\ Faculty, Saint Petersburg, Russia
}

\begin{abstract}
The purpose of the study is to formulate the concept of "environmental and legal culture", to identify its main properties and characteristics, to designate the methodological apparatus of its research; to substantiate the importance of an integrated approach and an axiological research method. The object of the research is the "environmental and legal culture" itself, and the subject is its structure, functions and processes of its objectification. Structural, functional, and comparative research methods became the methodological basis. The research results: the concept of "environmental culture", "environmental and legal culture" was formulated; the necessity of applying an integrated approach and an axiological method to the study of the phenomenon of "environmental and legal culture" was substantiated; the interrelation of legal awareness, education and enlightenment, legal technique and political guidelines of the Concept of sustainable development as characteristics of the concept of "environmental and legal culture" and the phenomena that predetermine and characterize it, are revealed. The authors emphasize that the "environmental and legal culture" is formed primarily on the basis of the norms of Environmental law, and not on the entire array of humanitarian and natural science knowledge about the environment as a whole. The novelty of the work is determined by the approach itself to substantiating the requirement for an integrated approach and an axiological method to study the content of the concept of "environmental and legal culture".
\end{abstract}

Keywords: environmental research, sustainable development, ethics in the protection of environment, environmental legislation

\section{Introduction}

The concept of "environmental and legal culture" objectifies in itself political, legal, socially significant, culturological, and ecological components. This multi-segment nature of the phenomenon predetermines the formation of an independent methodological mechanism of scientific and legal research.

\footnotetext{
${ }^{1}$ Corresponding author: klyukanova.1@yandex.ru
} 
This issue occupies fairly extensive information and research space in Russian science, in which a uniform scientific and analytical attitude has not been developed. The multilevel nature of the scientific problem is due to the peculiarities of the basic segments of the concept: "culture", "legal culture", "Environmental law" and their systemic interpretation.

The influence of cultural and philosophical views on the content of the considered problem field is evident. A culture, the understanding of which is possible exclusively through the prism of human activity (taking into account not only the result of this activity, but also the way of its implementation) can be defined as a special accumulated and transmitted spiritual experience of human communities, the content of which is the value (special positive) meanings of phenomena, norms, forms, and ideals, expressed in signs [1]. For legal scientific research, it is significant that "culture" is a source of regulating social interaction, as well as the behavior of people and society.

The authors consider that the level of environmental legal awareness, education and enlightenment, legal technique and political guidelines of society, public and social interaction, which are global in the 21 st century, scientific views and a responsible ecologically significant attitude towards the environment as a universal enduring value and good, the use and protection of which must be performed within the framework of a carefully developed legal field - are those characteristics that allow to define the "environmental and legal culture" and assess its level and condition. This postulate led to the hypothesis of the research.

\section{$2 \quad$ Methods}

The research methodology depends on the integrative and interdisciplinary nature of Environmental law. The work uses approaches and methods capable of solving problems of a complex level of knowledge. Traditionally, complex [2], integrated [3] and differentiated [4] approaches are applied to the study of Environmental law as a branch of law, as well as structural, systemic, functional, and axiological research methods.

\section{$3 \quad$ Results and discussion}

"Environmental and legal culture" is a prerequisite for ensuring environmental law and order, environmental safety, and implementation of the Concept of sustainable development. It is formed on the basis of the norms, first of all, of the Environmental law, the legal consciousness formed on its basis, and not all the accumulated knowledge about the environment as a whole, therefore, the characteristics inherent in the Environmental law as a branch of law and scientific direction, as well as its values, are extrapolated to some extent to the content of the concept of "environmental and legal culture".

Environmental law is an independent branch of the Russian legal system, a modern scientific and political direction, which "paradoxically" [5] combines legal, environmental, natural resource, political, philosophical, culturological and innovative segments. Environmental law is a unique, universal and complex branch of the Russian legal system that regulates public relations regarding the use and protection of natural resources and the environment, as well as ensuring the environmental safety of individuals, society and the state. Its intensive and dynamic development, implemented within the framework of an interdisciplinary paradigm setting, leads to creating a new type of understanding of the modern culture of legal regulation of environmental and legal social relations [6].

"Legal culture" is a type and an integral part of culture as such and is invariably the object of research of Russian legal science. The rationalistic positivist scientific paradigm, 
which has a priority in Russian legal studies, has formulated its understanding of the term. L.S. Yavich noted that the concept of "legal culture" includes all socially positive components of legal reality that have been accumulated by the humanity in the course of their social development and that contribute to the progress of civilization - it is characterized by its historical character, continuity, is objectively determined by the state of economic and productive forces, is in a certain dependence on other elements of the material and spiritual culture of certain regions; has an integrative character; specific functions of positive influence on social development and maintenance of the conditions for the existence of society; characterized by the unity of the content and external aspects of its expression; ensures respect for the rights and freedoms of the individual [7].

The authoritative approach is the value approach, which understands by "legal culture" the qualitative state of the legal life of society due to the social, spiritual, political, and economic system and sees its value in ensuring a stabilizing balance of forces and interests of society. As its main elements, it includes legal awareness, legal science, legal acts, law enforcement activity, the implementation of the principle of the supremacy of law, as well as the guarantee of respecting human rights and freedoms [8].

There are other approaches: the systemic approach interprets "legal culture" as a system of materialized and ideal elements related to both the sphere of force of law and their reflection in the minds and behavior of people; within the framework of the activity approach, it is considered as the result and method of legal activity (special attention is paid to legal technique); in the context of the sociological approach, it is considered as a characteristic of the level of legal phenomena at a certain stage of the development of society and as a qualitative characteristic of the perception of law and legal behavior of an individual (mainly sociological research methods are used); the information-semiotic approach considers it as a synthesis of all legal information that is accumulated and transmitted in society with the help of sign systems created by people [9]; a morally oriented approach examines it through the prism of environmental ethics and the responsibility of the humankind for the state of the environment [10].

The definition of the term "environmental culture", despite the active use of its implementation, is not formulated in the norms of Russian federal legislation. At the international legal level, there is, for example, such a definition: "domestic and world experience of harmonious interaction between a person and nature" [11]. The regional legislator proposed their own definitions, for example: "a set of environmental consciousness and environmental behavior of a person, a way of organizing and developing vital activities in the system of value orientations and environmental knowledge, skills and abilities" [12].

Traditionally, "environmental culture" is considered by Russian legislation in connection with ecological education, upbringing and enlightenment (for example [13]).

From the point of view of the political process, the concept of "environmental culture" is inextricably linked with the implementation of the Concept of sustainable development a program of action by the world community, providing for harmonious economic, political, social and cultural development in a favorable environment [14]. It focuses primarily on the individual who has the fundamental right to freedom, equality and a favorable life in an environment, the quality of which allows to lead a dignified and prosperous life, and bears the primary responsibility for protecting and improving the environment for the benefit of present and future generations.

It is required to take into account the unifying factor - the importance of a favorable environment as a universal enduring value of all human communities, objectifying in itself a general public interest, which requires the development of a personal ("environmental 
culture" is also an integral part of personality culture) and collective awareness of the need to develop "environmental culture" and form a system of responsible value environmentally significant orientations. "Environmental culture" acts as an element of social, public-state and interstate progressive interaction in the field of ecology, as the basis of communication and dialogue, it embodies the ideas of unity (interpreted in the spirit of common interest partnership and convergence of interests) and justice, which have fundamental character [15]. Environmental problems have far-reaching social consequences, and their solution requires radical changes in public consciousness and attitudes, as well as new legislative frameworks [16].

"Environmental culture" is defined as a human-created material and ethical environment of an ecologically-oriented social and personal responsible consciousness, as well as the processes of spreading ecologized principles and values that go beyond the sphere of nature management and environmental protection, penetrating into all spheres of social thought, contributing to the conservation of natural diversity and favorable conditions for human existence and development, as well as aimed at ensuring the environmental safety of society [17].

"Environmental and legal culture" is a type of "legal culture"; in some cases, it is identified with "ecological culture", which is not correct. "Environmental and legal culture" should be understood as such a state of individual and social consciousness and legal awareness, which predetermines the compliance of any environmentally significant activity of subjects with legal norms; at the same time, there is also a feedback - the technical and substantive level of legal norms, their knowledge, understanding and interpretation, as well as the level of implementing the environmental rights of citizens and ensuring environmental safety depend on the level of "environmental and legal culture" of society.

\section{Conclusion}

Analyzing the methodological methods of studying the phenomenon of "environmental and legal culture", the following approaches are noted: differentiated, integrated and complex. An integrated approach seems to be the most methodologically justified, since it takes into account the versatility, multi-structural and multitasking character of the examined phenomenon. This approach, developed within the framework of the postmodern post-nonclassical scientific paradigm with its pluralistic and synergistic attitudes, is the most modern scientific approach. The optimal research method is the axiological one, based on the value attitudes of recognizing the importance of a favorable environment and environmental safety.

When studying the concept of "environmental and legal culture" it is required to take into account the factors that have a direct impact on the development of a special comprehensive approach to a scientific problem: axiological traditions developed by culturology and philosophy; general legal methodological guidelines developed by the legislator, law enforcement practice and doctrine; functional features of the state of Environmental law - its structure, characteristics and political and value attitudes.

\section{References}

1. V.P. Bolshakov, E.P. Borzova, S.N. Ikonnikova, Culturology: textbook (Prospekt, Moscow, 2011)

2. M.M. Brinchuk, Environmental Law, 6, 1-28 (2004) 
3. S.A. Bogolyubov, M.K. Suleimenov, Environmental Law, 4, 32-38 (2014)

4. M.M. Brinchuk, Environmental Law, 1, 6-14 (2008)

5. R.J. Lazar, The Making of Environmental Law (The University of Chicago Press, Chicago, 1992)

6. L.G. Klyukanova, Scientific Notes of the Faculty of Law, 32(42), 5-18 (2014)

7. L.S. Yavich, Sushchnost prava. Sotsialno-filosofskoe ponimanie genezisa, razvitiya i funktsionirovaniya yuridicheskoi formy obshchestvennykh otnoshenii [The essence of law. Socio-philosophical understanding of the genesis, development and functioning of the legal form of social relations] (LSU Publishing house, Leningrad,1985)

8. S.S. Alekseev (ed.), Teoriya gosudarstva i prava Uchebnik dlya yuridicheskikh vuzov i fakultetov [Theory of State and Law: textbook for higher educational institutions and faculties of law] (NORMA-INFRA-M, Moscow, 2000)

9. V.N. Gulyaikhin, Questions of Law and Politics, 4, 135-153 (2013)

10. N.N. Moiseev, Social Sciences and Modernity, 6, 131-139 (1994)

11. Recommendatory Legislative Act, approved by the Resolution of the Interparliamentary Assembly of the CIS Member States dated February 17, 1996, "On environmental education of the population", art. 1, in Information Bulletin of the Interparliamentary Assembly of the CIS Member States, 10, 249 (1996)

12. Law of the Krasnodar Krai dated December 26, 2012. No. 2630-KZ “On environmental education, enlightenment and the formation of environmental culture of the population of the Krasnodar Krai", art. 3, in Information Bulletin of the Legislative Assembly of the Krasnodar Krai, 3, 3 (2013)

13. Federal Law No. 7-FZ “On environmental protection”, Chapter XIII, in Rossiyskaya Gazeta (January 12, 2002)

14. UN Declaration on environment and development - 1992, in Public International law. Collection of documents, 2, 132-135 (Vek, Moscow, 1996)

15. U. Beyerlin, T. Marauhn, International Environmental Law (Hart Publishing LTD, UK, 2011)

16. A. Kiss, D. Shelton, Manual of European Environmental Law Cambridge (University press, Cambridge, 1997)

17. L.G. Klyukanova, Education and Law, 5, 261-270 (2018) 